\title{
EXPERIENCE OF FORMING PROFESSIONAL AND COMMUNICATIVE COMPETENCY OF FUTURE SOCIAL WORKERS IN EDUCATION SYSTEMS OF WESTERN EUROPEAN COUNTRIES
}

\begin{abstract}
The article analyzes the experience of forming professional and communicative competency of future social workers in the education systems of Western European countries, in particular, France, Germany and Switzerland. On the basis of generalization of the studied data it has been found out that each country has its own techniques of forming professional and communicative competency of social workers, which are peculiar to its own specific character and based on the well-established traditions of a particular society. At the same time it has been defined that basic qualities which social workers should have for efficient professional and communicative activity (striving for communication, ability to establish communicative interaction with different members of society, knowledge of professional speech etiquette etc.) are common for all countries. The content of the forming professional and communicative competency of students in the education systems of France, Germany and Switzerland has been analyzed. Forms and methods used in the educational process in order to develop professional and communicative competency of the future social workers have been defined. It has been found out that the theoretical training of students is closely linked to the usage of acquired communication skills and habits in the process of practical training, which is given much study time aimed at obtaining by the students a maximum professional experience in the real terms of communicative interaction. It has been defined that a modern pattern of forming professional and communicative competency of future social workers in the higher educational establishments of Ukraine should be created in the unity of social factors of our country and foreign experience.

Key words: communicative competency, professional and communicative competency of social workers, social worker, the content of study, communicative interaction, interactive methods, forming, practical training.
\end{abstract}

\section{INTRODUCTION}

In the context of modern society social workers must be ready to perform complex professional tasks in the process of interaction with different groups of people. Regarding this a priority task of modern pedagogical education in Ukraine is the complex training of future professionals to various professional situations that principally lies in the forming of their professional and communicative competency since the ability to build effective communicative interaction with customers is the key to successful professional activity of a social worker in general.

Considerable attention is paid to the forming of social workers' professional and communicative competency during the training in this field within the education systems of Western European countries, in particular, France, Germany and Switzerland. Of course, on 
the one hand, the process of forming is affected by traditions of a certain ethnic group, social policy and the realities of modern society. However, the main qualities which social workers should have for effective professional and communicative activity are common for all countries. We qualify them as a striving for communication, ability to establish communicative interaction with different members of society, knowledge of professional speech etiquette, ability to convince and find compromise in human relations etc.

Taking it into account the study and implementation of progressive ideas of foreign experience is significant in creation of a national pattern of forming professional and communicative competency of social workers, in particular, in the developed Western European countries such as France, Germany and Switzerland.

\section{THE AIM OF THE STUDY}

The aim of our study is to analyze the experience of forming professional and communicative competency of future social workers in the education systems of Western European countries, in particular, France, Germany and Switzerland.

\section{THEORETICAL FRAMEWORK AND RESEARCH METHODS}

The theoretical basis of the study makes up the works of scholars on problems of forming professional and communicative competency of social workers in the education systems of France, Germany and Switzerland (O. Bartosh-Pichkar, G. Lieshchuk, V. Polishchuk, O. Pryshliak, V. Tymenko, N. Vydyshko etc.).

To achieve a set goal the following methods of investigation were used: analysis of scientific literature, synthesis, generalization, systematization and comparison with the help of which theoretical and practical approaches to forming professional and communicative competency of future social workers in the education systems of France, Germany and Switzerland were compared.

\section{RESULTS}

In foreign literature the number of patterns of social workers' professional training has increased. Thus, in Austria, Belgium, Germany, France and Switzerland the social workers' training is carried out outside the system of university education. In the Czech Republic, Bulgaria, Greece, Norway, Poland and Slovakia both university and extra-university types of training are used. In Estonia, Finland, Iceland, Sweden, the United States, likewise in Ukraine, the training of social workers is mainly carried out by universities.

Today in Europe there are over 400 educational establishments where one can get a qualification of a social worker. Quite a lot of students from different countries (Austria, Belgium, Denmark, Finland, France, Ireland, Switzerland, UK - 100-200; Greece, Israel, Portugal, Sweden, Turkey - 400; Germany - 1000-2000) study there.

Unlike the system of social education in Ukraine, which is aimed at training of multi-skilled specialists in social work with an emphasis on theoretical knowledge, the educational establishments of France train social workers in the specialization which is developed in three main directions: social assisting (l'assistance sociale), specialized education (l'éducation spécialisée), animation (l'animation). Furthermore, it should be noted that the training programs of social workers in France contain considerably fewer number of educational subjects of comprehensive, humanitarian, socioeconomic and basic training focusing on professional and special disciplines and spending more than half of the study time practicing (Борозна, 2005).

Forming of professional and communicative competency of future social workers is one of the priority tasks of social workers' professional training in France and begins with the first steps of mastering this profession. Fundamentals of professional communication, 
peculiarities of interpersonal interaction, norms and rules of behaviour in society are covered while studying basic disciplines, among which "Pedagogy and psychology", "Structure of institutions of social work", "Social environment", "Relationships among people" etc. In general, they correspond to national disciplines such as "Sociology", "Psychology", "Ethics", "Pedagogy", "Law" etc.

Thus, the purpose of the training unit "Pedagogy and psychology" is to form the knowledge of psychological and pedagogical foundations of social work in future professionals, fundamentals of interpersonal communication, to develop skills of interpersonal relationships analysis, to teach to identify types of communicative behaviour in conflict situations, to find ways out of conflict etc. The structure of the training unit "Social environment" comprises subjects "Social norms and social control", "Cultural policy" aimed at acquaintance of students with the subjects of social activity, norms of communicative behaviour in society, directions of social work, structure of society, organization of social services and institutions (Лєщук, 2005).

Also, the curriculum provides a number of professional disciplines, mainly of practical nature aimed at building professional and communicative competency of future social workers, namely, "Theory and practice of social service", "Social activity and institutions", "Methods of social work", "Institutional and legal context of mechanisms of providing social assistance and the implementation of social activity", "Rights and obligations of consumers and professionals", "Project methodology", "Methodology of intervention", "Physiological, mental, economic and cultural human development", "Preparation of report documentation at practical training". In the process of study of the abovementioned subjects students gain knowledge about directions of social policy and customers' needs, get acquainted with the content and technologies of professional and communicative interaction with different groups of clients, learn to diagnose professional and communicative situations, establish communicative interaction with customers, plan and provide assistance according to objectives, evaluate results of work.

Furthermore, the curriculum provides study of special subjects exceptionally of communicative orientation, namely, "Professional communication and cooperation with partners" and "Dissemination of informing". Academic discipline "Professional communication and cooperation with partners" provides advanced study of the following topics: "Professional communication", "Business language", "Coordination of work of members of multiprofessional team", "Organization and holding of meetings and gatherings", "Professional speech etiquette", "Technologies of conflict solutions" etc. Discipline "Dissemination of informing" provides the acquisition of skills in informing and communication technologies, mastering the skills of collecting, processing and storage of informing (Лєщук, 2005).

It should be noted that at the present stage within the modernization of education in the sphere of social work of France the problem of including into curriculum of professional training the course of "Foreign language" is regarded that will greatly expand communication opportunities of students and will provide future professionals with higher mobility (Борозна, 2005).

In Germany the profession of a social worker can be obtained in collegesinstitutes and also in recently established universities, which also offer some courses of social workers. It is important that universities and colleges in Germany have a high degree of constitutionally guaranteed independence. It enables them to independently solve all academic problems relating curricula, examinations, admission of students etc. Owing to this autonomy the content and structure of the curricula differ from different education institutions of Germany (Тименко, 2012). 
In particular, common elements of the curricula of social workers' training can be grouped as follows: social work and social pedagogy (history, theory, organization and institutions, methods of work); social sciences (sociology, social policy, political science, economics, statistics, empirical social researches); psychology and pedagogy (progressive psychology, therapeutic methods, theory and practice of education, socialization theory); health (medical aid provision, medical examination); legal and public management (legislation on family, youth, social welfare, social security, labour and management); media, art, sports (Тименко, 2012).

Much attention in the learning process is focused on mastering by students the subjects of communicative orientation aiming at forming professional and communicative competency of future social workers in this field. Such subjects as "Psychology and pedagogy", "Methods of work with clients", "Socialization theory", "Mass-media" provide basic knowledge of theory on professional communication, peculiarities of behaviour in society, forms of communicative interaction with different groups of clients, tools for informing transfer etc.

Consolidation of theoretical material on fundamentals of professional communication is carried out by students in the process of study of practice-oriented courses ("Sphere of professional activity", "Methods of professional activity"), where during seminars using methods of conversation, discussion, role play, working in small groups, students learn to think independently, analyze problem situations, formulate and prove their own point of view etc. (Пришляк, 2007).

In order to form professional and communicative competency of future social workers much attention is given to the use of role-playing games, which are regarded both as a method and as a social-pedagogical tool. The course "Games" is a constituent part of the subject "Media pedagogy", which provides mastering of traditional communicative games by students, during which professional situations are acted out that require analysis and decision. Owing to the use of this method, future social workers develop gained communication skills and obtain experience of professional and communicative interaction.

Working in small groups is also a common method. The use of this method involves division of a student group into micro-groups with the purpose of analyzing and solving certain problematic professional situation. After the analysis in micro-groups the taken decision is brought up by each of the groups for the general discussion, during which conclusions are drawn and general solution is accepted. Applying the method of working in small groups promotes students' ability to communicate in a group, hold a discussion, defend their own opinion etc. (Пришляк, 2007).

Forms of learning outcomes assessment at German universities are credits, exams, reports, written reports on practical training, writing course papers and diploma papers. In particular, it is important that credits there are taken in three forms: written homework, oral answer, written report in class. Due to the use of various assessment forms both oral and written speech of students is checked (Пришляк, 2007).

A significant role for the forming of professional and communicative competency of future social workers in Germany is a internship. Future social workers have several types of practical training: preprofessional, introductory, specialized during basic study and professional practical training as well. Practical training may be accompanied by theoretical studies, for example, during the project study or be continuous (block practical training). Under such circumstances students can immediately try the obtained professional and communicative knowledge and skills during practical training and check their abilities in 
the real situation of professional and communicative environment that contributes to their acquiring the experience of professional communication (Тименко, 2012).

Profession of a social worker in Switzerland can be obtained in special schools of social work. 10 schools of social work function in 26 cantons in Switzerland, which provide education at the college level. There is also a university which prepares social workers, but it works according to the program of social sciences and is not included into the Association of Schools of Social Work (Vallimann, 1993).

Specificity of forming professional and communicative competency of social workers in schools in Switzerland is stipulated by the fact that the content, forms and methods of social work are mainly conditioned by the non-governmental initiatives at the local level and at the level of cantons. Thus, one of the criteria of selection of students for schools of social work is the presence of life experience of applicants, that is why usually older people become students of these schools. According to the requirements of the Association of Schools of Social Work applicants should have a completed 12-year course of study at a secondary school, good knowledge of a foreign language, possess basic communication skills necessary for work with clients and have at least one year of work experience in the field related to social work. Some schools put additional requirements. They are to take courses on the fundamentals of social work or have real-life experience of social work (Валлиманн, 1993).

The primary purpose of schools of social work in Switzerland is to prepare students for practical social work. Hence, much attention in education is given to the forming of professional and communicative competency of future specialists.

The theoretical training of social workers includes a number of courses aimed at forming professional and communicative competency, namely, "Pedagogy", "Psychology", "Sociology", "Social policy", "Social problems", "Philosophy", "Ethics", "Aspects", "Social work with individual clients, family, group", "Public relations in social work" etc. As a result knowledge on fundamentals of professional communication and skills of understanding and analysis of problem professional situations are obtained, and the abilities to use verbal and non-verbal means of speech, knowledge of speech etiquette, apply various methods and techniques of establishing communicative interaction with different groups of clients are formed (Валлиманн, 1993).

It should be noted that a significant role in the forming of professional and communicative competency of future social workers in Switzerland has students' practical training, which is given not less than three thousand hours of the training process, of which more than 180 days are held directly in the real-life conditions. In addition, at the request of the Association, a social worker should practice at least in two directions of social work, each of which should be attended at least 6 months under the supervision of the social worker who has a degree (Валлиманн, 1993).

The advantage of practical training in Switzerland is that while passing practical training, students have the opportunity to "try out" themselves and their level of professional and communicative competency in real-life environment of professional and communicative activity, reveal possible gaps in knowledge, improve communication skills and habits and gain experience of professional and communicative interaction with different groups of clients.

\section{CONCLUSIONS}

The performed analysis of foreign experience enables to state that the forming of professional and communicative competency in France, Germany and Switzerland is an 
integral part of training of future social workers in the education systems of these countries. This process is carried out systematically during the study of basic and special disciplines with the use of various methods and techniques aimed at enhancing communicative activity of students. Theoretical training is inextricably connected with the use of acquired communication skills and habits in the process of practical training, which is given much of the training so that students could obtain maximum professional experience in real-life environment of communicative interaction. The prospects for further research are the use of capabilities of foreign experience in the development of our own pattern of social workers' professional and communicative competency.

\section{REFERENCES}

1. Борозна, Г. (2005). Особливості підготовки соціальних працівників у структурі соціальної роботи Франції [Peculiarities of Training of Social Workers in the Structure of Social Work of France]. Практична психологія та сочіальна робота [Practical Psychology and Social Work], No 9, pp. 69-71 (in Ukrainian).

2. Валлиманн, И. (1993). Специфика подготовки социального педагога в Швейцарии [Specificity of a Social Teacher's Training in Switzerland]. In : Yarkina, T., Bocharova, V. (Eds.). Теории и принщипы сочиальной работы: отечественный и зарубежный оnыт [Theories and Principles of Social Work: Domestic And Foreign Experience]. М.-Тула : АСОПиР РФ, pp. 287-295 (in Russian).

3. Лєщук, Г. (2005). Особливості організації практичної підготовки соціальних працівників у Франції [Peculiarities of Organization of Social Workers' Practical Training in France]. Наукові записки Тернопільського національного педагогічного університету. Серія : Педагогіка [Scholarly Notes of Ternopil National Pedagogic University. Series : Pedagogy], No 2, pp. 111-115 (in Ukrainian).

4. Пришляк, О. (2007). Змістовий компонент професійної підготовки соціальних педагогів у Німеччині [Conceptual Component of Social Workers' Professional Training in Germany]. Наукові записки Тернопільського національного педагогічного ун-ту ім. В. Гнатюка. Серія : Педагогіка [Scholarly Notes of Ternopil National Pedagogic University. Series : Pedagogy], No 1, pp. 39-44 (in Ukrainian).

5. Тименко, В. (2012). Особливості підготовки соціальних працівників та соціальних педагогів до роботи з молоддю в Німеччині [Peculiarities of Social Workers and Social Teachers' Training to Work with Youth in Germany]. In: Збірник наукових праць звітно-наукової конферениї викладачів НПУ ім. М. П. Драгоманова [The Collection of Works of Report-Scientific Conference of Lecturers in Drahomanov National Pedagogic University]. К. : Національний педагогічний університет ім. М. П. Драгоманова, pp. 214-216 (in Ukrainian). 